\title{
AUXÍLIO-RECLUSÃO E SUA RELAÇÃo COM O PRINCÍPIO DA IGUALDADE
}

\author{
Rubiane Galiotto ${ }^{1}$ \\ Patrícia Noll ${ }^{2}$
}

\section{RESUMO}

No presente trabalho objetiva-se analisar a relação que existe entre a concessão do AuxílioReclusão e a aplicação do Princípio da Igualdade através do método analítico-dedutivo com a análise dos aspectos doutrinários e legais acerca do assunto. A legislação, após a Emenda Constitucional $n^{\circ}$ 20/1998, prevê o requisito baixa-renda para a concessão do auxílio-reclusão. Desta forma, a concessão do benefício fere o princípio da igualdade visto que é assegurado o benefício previdenciário apenas às famílias dos segurados de baixa-renda. Diante de tal discriminação, as famílias dos segurados reclusos que recebiam valor maior que o estipulado na lei são deixadas desamparadas.

Palavras-chave: Direito Previdenciário; Auxílio-Reclusão; Princípio da Igualdade

\section{RECLUSION-AID AND ITS RELATIONSHIP WITH THE PRINCIPLE OF EQUALITY}

\begin{abstract}
This study aims to analyze the relationship between Reclusion-Aid and the application of the Principle of Equality through the analytical-deductive method with the analysis of doctrinal and legal aspects on the subject. The legislation after the Constitutional Amendment $n^{\circ}$ 20/1998 foresees a low-income requirement for granting Reclusion-Aid. Therefore, the benefit harms the Principle of Equality since it ensures the Pension Benefit only to the families with lowincome. Before such discrimination, the families of policyholders inmates who received value greater than the stipulated in law are left helpless.
\end{abstract}

Keywords: Social Security Law; Reclusion-Aid; Principle of Equality

\footnotetext{
${ }^{1}$ Graduação em Direito pela Universidade de Caxias do Sul - USC, Rio Grande do Sul, (Brasil). Especialista em Direito Público, ESMAFE/RS; Advogada. E-mail: rubianegaliotto@gmail.com

${ }^{2}$ Graduação em Direito pela Universidade de Caxias do Sul - UCS, Rio Grande do Sul, (Brasil). Professora da Graduação e Pós Graduação de Direito - Universidade de Caxias do Sul, Rio Grande do Sul, UCS (Brasil). Email:pnoll@ucs.br
} 


\section{CONSIDERAÇÕES INICIAIS}

Como Lei Maior em nosso ordenamento jurídico, encontra-se a Constituição da República Federativa do Brasil de 1988, sendo esta a norteadora de todo o ordenamento jurídico.

O Direito Constitucional é fundamental para a compreensão do Direito Previdenciário pois qualquer regramento que possibilita a concessão de benefícios previdenciários deve ser baseado na Constituição.

Sabe-se que a concessão dos benefícios previdenciários no Brasil foi ao longo dos anos sendo modificada por emendas constitucionais e novas leis regulamentadoras.

Nessas inúmeras alterações, alguns benefícios foram sendo criados e outros majorados visando uma abrangência maior da Previdência Social frente à sociedade. Porém, em meados de 1991 devido ao aumento da expectativa de vida da população, um caminho inverso começou a ser traçado pela Previdência Social ao restringir direitos dos segurados.

Em se tratando de restrições, uma das mais importantes modificações no auxílioreclusão foi trazida pela Emenda Constitucional n ${ }^{\circ} 20$ de 1998 que acabou por alterar a redação do art. 201 em seu inciso IV da Constituição Federal passando a dispor o seguinte:

\footnotetext{
Art. 201. A previdência social será organizada sob a forma de regime geral, de caráter contributivo e de filiação obrigatória, observados critérios que preservem o equilíbrio financeiro e atuarial, e atenderá, nos termos da lei, a:

$[\ldots]$

IV - salário-família e auxílio-reclusão para os dependentes dos segurados de baixa renda. (BRASIL. Constituição da República Federativa do Brasil, 1988, art. 201)
}

Diante desta alteração, o auxílio-reclusão passou a ser devido apenas aos segurados de baixa-renda, restringido portanto a concessão deste benefício. Se antes todo e qualquer segurado que possuísse os requisitos para a concessão do auxílio-reclusão tinha tal benefício garantido para seus dependentes, agora é preciso que possua baixa-renda para que o benefício seja devido a seus familiares.

Vislumbra-se neste assunto, um campo de conhecimento quase inexplorado pelos doutrinadores e juristas, fazendo surgir assim o interesse no tema da concessão do auxílioreclusão e sua relação com o princípio da igualdade. Ademais, percebe-se que a alteração gerada pela emenda constitucional de forma a restringir a concessão do auxílio-reclusão, não 
causou na população em geral desconforto, uma vez que existe grande preconceito e resistência por parte destes em aceitar a existência do auxílio-reclusão.

$\mathrm{O}$ artigo portanto pauta-se principalmente na relação que existe entre a concessão do auxílio-reclusão e o princípio da igualdade evidenciando as consequências do surgimento do requisito baixa renda no ordenamento jurídico.

Para isso, a análise doutrinária e legal através do método analítico-dedutivo foi essencial para revisar a literatura sobre o tema, promovendo um levantamento de fontes bibliográficas com a seleção dos aspectos mais relevantes para a presente pesquisa.

\section{PRINCÍPIO DA IGUALDADE}

Analisando a relação que existe entre a concessão do auxílio-reclusão e o princípio da igualdade, trata-se primeiramente do princípio da igualdade.

Historicamente, o princípio da igualdade surgiu ainda na antiga Grécia conforme ensina Francisco Bruno Neto (2011, p. 477):

\footnotetext{
Esse princípio existe há mais de vinte séculos, com os primeiros ensaios de governação democrática entre os filósofos gregos. É o denominado princípio da isonomia, proclamado por Heródoto, Péricles e, notadamente, por Aristóteles, que o desenvolveu como fundamento do seu conceito de democracia.
}

Segundo Eduardo C. B. Bittar (2007), Platão foi o primeiro grande pensador a trazer ao público a concepção da igualdade quando da problemática acerca do homem em sociedade. Ao analisar a desigualdade natural dos seres humanos com a crença de que uns haviam nascido para comandar e outros para serem servos, Platão analisa o princípio da igualdade entre os homens em seus escritos. É uma ideia de desigualdade natural que gera desigualdade social na Antiguidade.

Naquela época, o conceito de igualdade atrelado ao conceito de democracia era diferente do pensado na atualidade eis que em Atena somente os cidadãos livres e maiores de 20 anos podiam exercer a cidadania, estando automaticamente excluídos os escravos, estrangeiros e as mulheres.

Após, os cristãos também possuíam a concepção de igualdade nos escritos da Bíblia que descrevia a vida de Jesus Cristo. Segundo Eduardo C. B. Bittar (2007), a Bíblia afirma que todas as pessoas foram criadas à imagem e semelhança de Deus, ou seja, todos são iguais em 
sua origem, trazendo à tona o embrião do ideal de igualdade para os cristãos. Porém, essa igualdade não era percebida na prática, uma vez que o cristianismo, em especial a Igreja Católica Romana, aceitou por séculos a escravidão, a desigualdade entre os povos e entre os próprios homens e mulheres - enquanto gênero.

Posteriormente vem a idade moderna com ideais de pensadores como Hobbes com a ideia de igualdade natural entre os homens. Para este pensador, Eduardo C. B. Bittar (2007), afirma que a desigualdade proveniente da lei civil era bem aceita. Para ele era normal que existisse desigualdade advinda da lei civil resultante de um contrato existente entre a sociedade. Ou seja, todos partiriam de uma igualdade perante a lei e a partir deste pacto surgiriam desigualdade resultantes das oportunidades e êxitos em sociedade. Iniciava ali uma primeira ideia de igualdade formal.

Seguindo, Eduardo C. B. Bittar (2007) indica que o pensador Rousseau acredita que a igualdade seria alcançada com uma sociedade sem escravidão. Somente desta forma, todos os cidadãos livres teriam igualdade de oportunidades e eliminariam a desigualdade de fato. Porém esta igualdade civil também é uma igualdade formalista ao passo que analisa apenas o ser humano como pessoa e não o contexto social a que está inserido, equiparando ricos e pobres como se tivesses as mesmas oportunidades em sociedade.

É esta concepção de igualdade formal e perante a lei que não responde aos anseios dos revolucionários da Revolução Industrial. Ali surge a ideia de Karl Marx segundo Eduardo Heldt Machado e Raquel Fabiana Lopes Sparemberger (2014, p.4)

[...] entendendo que havia uma inegável desigualdade material, econômica e social entre os homens em sociedade, busca, com a sua teoria, a eliminação dessa desigualdade. Por isso, fora um dos primeiros pensadores que pensou a efetivação da igualdade através da erradicação da desigualdade.

Para Marx, existe uma desigualdade material entre o proletariado e a classe proprietária de empresas fazendo com que os trabalhadores sejam explorados e a classe dominante fique cada vez mais poderosa e financeiramente abastada. Surge então a proposta do comunismo como proposta da erradicação da desigualdade social na busca pela igualdade de forma absoluta. 
Já na Revolução Francesa, o princípio da igualdade teve papel fundamental e está aposto já nos artigos $1^{\circ}, 6^{\circ}$ e 13 da Declaração dos Direitos do Homem e do Cidadão de $1789^{3}$ e mais tarde no texto da Constituição da França. O princípio da igualdade naquele tempo tinha um viés mais formalista conforme o doutrinador Carlos Roberto de Siqueira Castro (1983) que diz que o princípio da igualdade objetivava servir de "poderoso instrumento na reação contra os privilégios pessoais que, com variantes puramente culturais, vigorou por toda a antiguidade, na Idade Média e no Renascimento absolutista."

A igualdade naquela época era puramente formal, objetivando apenas, conforme Carlos Roberto de Siqueira Castro (1983, p.38) "tratamento legislativo diverso para idênticas ou assemelhadas situações de fato". Desta forma, a igualdade material e social naquele momento não era a principal preocupação dos franceses que lutavam por direitos positivados de forma igualitária, uma vez os feudais, aristocráticos e religiosos possuíam privilégios a perder de vista.

Saindo da base histórica e entrando no campo conceitual, é preciso notar que o princípio da igualdade é conceituado basicamente de duas formas: igualdade material e formal. A igualdade denominada material, objetiva uma equiparação de forma social dos indivíduos, não apenas perante a lei. Objetiva ainda uma sociedade perfeita onde todos seriam exatamente iguais e portanto, teriam igualdade em oportunidades e direitos. Para tal situação, enuncia Celso Ribeiro Bastos (2002, p. 317) que: "Essa igualdade contudo, a despeito da carga humanitária e idealista que traz consigo; até hoje nunca se realizou em qualquer sociedade humana".

Sobre a igualdade formal cita-se Celso Ribeiro Bastos (2002, p. 317) que assim o define: "Esta consiste no direito de todo cidadão não ser desigualado pela lei senão em consonância com os critérios albergados ou ao menos não vedados pelo ordenamento jurídico."

Claro que o princípio da igualdade, como todos os demais, não é absoluto. Nota-se normas ao longo da Constituição que positivam diferenciações entre classes, grupos e indivíduos.

\footnotetext{
${ }^{3}$ Art. $^{\mathbf{0}}$. Os homens nascem e são livres e iguais em direitos. As distinções sociais só podem fundamentar-se na utilidade comum. Art. $6^{\mathbf{0}}$. A lei é a expressão da vontade geral. Todos os cidadãos têm o direito de concorrer, pessoalmente ou através de mandatários, para a sua formação. Ela deve ser a mesma para todos, seja para proteger, seja para punir. Todos os cidadãos são iguais a seus olhos e igualmente admissíveis a todas as dignidades, lugares e empregos públicos, segundo a sua capacidade e sem outra distinção que não seja a das suas virtudes e dos seus talentos. Art. 13 $^{\circ}$. Para a manutenção da força pública e para as despesas de administração é indispensável uma contribuição comum que deve ser dividida entre os cidadãos de acordo com suas possibilidades.
} 
O que se deve ressaltar é que, segundo os ensinamentos de Rui Barbosa (1999), o princípio da igualdade busca tratar igualmente os iguais e desigualmente os desiguais, na medida em que se desigualam.

Sobre esta diferenciação dos indivíduos, cita-se Manoel Gonçalves Ferreira Filho (2008, p. 281) “O princípio da igualdade não proíbe de modo absoluto as diferenciações de tratamento. Veda apenas aquelas diferenciações arbitrárias, as discriminações."

A dificuldade encontra-se em definir exatamente os indivíduos que devem ser considerados "iguais" e os que devem ser considerados "desiguais" auferindo critério de desequiparação plausível.

\section{AUXÍLIO-RECLUSÃO}

O princípio da igualdade relaciona-se de forma importante com a concessão do auxílioreclusão, especialmente no que tange ao requisito baixa-renda. Antes desta análise, porém, cabe uma pequena explanação sobre os requisitos e conceito do benefício. $\mathrm{O}$ autor Fabio Zambitte Ibrahim, (2011, p. 661) define o benefício: “O auxílio-reclusão, assim como a pensão por morte, é benefício destinado exclusivamente aos dependentes do segurado, no caso, o preso. Este não percebe auxílio-reclusão, mas sim sua família."

Historicamente falando, o benefício foi incluído pela primeira vez no ordenamento jurídico brasileiro em 1933, com o IAPM - Instituto de Aposentadoria e Pensões dos Marítimos e logo após, em 1934, com o Instituto de Aposentadorias e Pensões dos Bancários - IAPB. A extensão a todos os segurados da Previdência Social veio apenas em 1960 com a Lei Orgânica da Previdência Social - LOPS.

O art. 43 da LOPS - Lei 3.807 de 26 de agosto de 1960 previa o seguinte:

Art. 43. Aos beneficiários do segurado, detento ou recluso, que não perceba qualquer espécie de remuneração da emprêsa, e que houver realizado no mínimo 12 (doze) contribuições mensais, a previdência social prestará auxílio-reclusão na forma dos arts. 37, 38, 39 e 40, desta lei.

$\S 1^{\circ} \mathrm{O}$ processo de auxílio-reclusão será instruído com certidão do despacho da prisão preventiva ou sentença condenatória.

$\S 2^{\circ} \mathrm{O}$ pagamento da pensão será mantido enquanto durar a reclusão ou detenção do segurado o que será comprovado por meio de atestados trimestrais firmados por autoridade competente. 
Desta forma, a família do segurado detento ou recluso, percebia o pagamento do benefício enquanto durasse a prisão do segurado, mediante a comprovação com atestados trimestrais firmados por autoridade competente.

Constitucionalmente falando, o benefício teve sua primeira referência da Constituição Federal de 1988, onde o art. 201, inciso I previa a concessão do benefício ao dependentes do segurado recluso.

Foi apenas em 1998 com a Emenda Constitucional no 20 que foi alterado o referido artigo para que o requisito baixa-renda fosse incluído no rol de condições de concessão do benefício.

Os requisitos necessários para a concessão do presente benefício são definidos basicamente em cinco pontos. O primeiro trata da necessidade de qualidade de segurado do preso, já que este benefício independe de carência. Desta forma, não há necessidade de contribuições previdenciárias para que os familiares façam jus ao benefício, basta apenas que exista a qualidade de segurado do preso no memento da reclusão.

Em que pese isso, recentes alterações na legislação apontam para a concessão do auxílio-reclusão ao cônjuge ou companheiro por um prazo determinando, de acordo com o preenchimento de alguns requisitos.

Não se consideram tais requisitos como carência para a concessão do benefício, mas apenas uma forma de limitação na concessão mediante o cumprimento de alguns critérios. $\mathrm{O}$ segurado recluso que não contribuiu por no mínimo dezoito contribuições até o momento da reclusão, ou não é casado ou vive em união estável há mais de dois anos no momento da reclusão, gera o direito ao benefício previdenciário de apenas quatro meses a contar da data da prisão.

Já os segurados reclusos que naquele momento, possuíam as dezoito contribuições vertidas ao RGPS, conviviam em união estável há mais de dois anos ou casados por igual tempo, possuem tabela progressiva de tempo para os dependentes receberam o valor do benefício. Dependentes com menos de vinte e um anos no momento da prisão, recebem até três anos de auxílio-reclusão. Já os entre vinte e um e vinte e seis anos de idade, percebem até seis anos de benefício. Os dependentes com idade entre vinte e sete e vinte e nove, percebem até dez anos de benefício, e os dependentes entre trinta e quarenta anos, percebem até quinze anos. Os dependentes entre quarenta e um anos e quarenta e três, recebem até vinte anos, e os que possuem idade a partir de quarenta e quatro anos, recebem vitalícia, enquanto perdurar a 
reclusão do segurado. Neste ponto, cabe destacar que o cônjuge inválido ou com deficiência recebe o benefício enquanto a invalidez ou deficiência perdurar.

O segundo ponto a ser analisado é a prisão. Aqui é preciso destacar que a prisão deve ser em regime fechado ou semi-aberto conforme o art. $116, \S 5^{\circ}$ do Decreto $n^{\circ} 3048$ de 1999 . O texto da lei fala apenas em prisão, não especificando que esta deva decorrer exclusivamente de sanção penal. Diante disso, doutrinadores como Daniel Raupp (2009), defendem a ideia de que os presos de forma cautelar, provisória, administrativa e civil também possuem direito ao recebimento deste benefício. Ainda neste ponto, cabe destacar que o exercício de atividade remunerada durante a reclusão não importa na perda do benefício previdenciário, objetivando estimular a reabilitação do preso para o convívio em sociedade.

O terceiro ponto que deve ser analisado é a comprovação da qualidade de dependente dos que receberão o benefício. Com fulcro no art. 16 da Lei no 8.231/91, os dependentes estão dispostos em classes, sendo que a classe anterior exclui o direito à prestação da classe seguinte. São beneficiários: I - o cônjuge, a companheira, o companheiro e o filho não emancipado, de qualquer condição, menor de 21 (vinte e um) anos ou inválido ou que tenha deficiência intelectual ou mental ou deficiência grave; II - os pais; ou III - o irmão não emancipado, de qualquer condição, menor de 21 (vinte e um) anos ou inválido ou que tenha deficiência intelectual ou mental ou deficiência grave.

Neste ponto, cabe destacar que recentes mudanças na classificação dos dependentes ocorreu com a edição da Lei n ${ }^{\circ} 13.146$ de 2015 que instituiu a lei brasileira de inclusão das pessoas com deficiência.

O quarto requisito trata do disposto no art. 116, caput do Decreto $\mathrm{n}^{\circ} 3048$ de 1999, onde está disposto que o segurado recluso não pode receber remuneração da empresa nem estar em gozo de auxílio-doença, aposentadoria ou abono de permanência em serviço durante o período em que estiver preso. Isso ocorre porque a existência de qualquer uma destas prestações ensejaria o sustento da família já que esta não ficaria desprovida de renda.

O quinto requisito e de maior destaque, é o requisito baixa-renda. Baseado na alteração feita pela Emenda Constitucional no 20 de 1998, o quinto requisito se encontra no art. 201, inciso IV da Constituição Federal, restringindo a concessão do auxílio-reclusão apenas dos dependentes do segurado que tenha baixa-renda.

Com a inclusão deste novo requisito, era necessária a criação de uma lei que disciplinasse o que seria entendido como baixa-renda. Até hoje, quase 20 anos depois, o art. 13 
da Emenda Constitucional é o único que serve de base para a aplicação do requisito na concessão do benefício. Com a falta de regulamentação, posicionamentos de que a renda considerada deveria ser a dos dependentes e não a do segurado começaram a surgir, opondo-se às teses de que a renda analisada deveria ser a do segurado recluso. Tendo em vista a divergência de entendimentos dos tribunais, o STF (Supremo Tribunal Federal) decidiu, através dos Recursos Extraordinários 486413/SP e 587365/SC no dia 25/03/2009, que a renda considerada para a concessão do auxílio-reclusão deve ser a do segurado.

Sobre o valor máximo que pode ser percebido pelo segurado para caracterizar a baixarenda, há uma portaria anual que informa o valor atualizado. No corrente ano, a Portaria Interministerial MTPS/MF no 1 de 08/01/2016, indica como valor máximo R\$ 1212,64 (um mil duzentos e doze reais e sessenta e quatro centavos) como remuneração do segurado no momento da reclusão.

Superada esta dúvida, é preciso analisar sob a luz do princípio da igualdade, a razoabilidade do fator discriminante disposto como quinto requisito.

\section{O REQUISITO BAIXA-RENDA E O PRINCÍPIO DA IGUALDADE}

O requisito em análise não existiu desde sempre no ordenamento jurídico, é obra da inovação advinda da Emenda Constitucional no 20 de 1998. Foi somente neste momento que a inclusão do requisito surge e abre brecha para o questionamento quanto à plausibilidade do fator discriminante baixa-renda. Sobre o assunto, cita-se Marcia Uematsu Furukawa (2006, p. 110) que diz:

[...]entendemos não haver correlação lógica entre o fato de o segurado recolhido à prisão ter auferido, antes da ocorrência do evento, essa ou aquela renda, e a caracterização da situação de necessidade de seus dependentes, já que é condição para que o benefício seja concedido, que a remuneração antes percebida pelo segurado esteja suspensa.

Como o benefício é substitutivo de renda, pode-se notar que tanto a família com renda superior ao permitido pode passar necessidade quanto a que possui renda dentro dos limites. $\mathrm{O}$ valor percebido pelo segurado antes da reclusão não influenciará na ausência de renda que ocorre quando a prisão é efetivada e a renda, não importando o valor, desaparece. 
Diante desta substituição, retirar o direito de alguns segurados de manter sua família recebendo prestação previdenciária quando encontrar-se recluso, fere de forma nítida a dignidade da pessoa humana e demais princípios e direitos fundamentais.

Sobre o assunto, cita-se Daniel Machado da Rocha e José Paulo Baltazar Junior (2003, p. 88) que falam o seguinte:

A alteração constitucional é merecedora de críticas, pois deixa ao desamparo a família do segurado com renda superior ao limite legal, impedido de trabalhar em virtude do encarceramento. Aliás, este benefício tem justamente a finalidade de prover a manutenção da família do preso.

A modificação trazida pela Emenda no 20 de 1998 é uma forma de restrição da concessão do benefício de auxílio-reclusão, já que exclui da proteção social, os segurados que possuem renda maior que a permitida. Tal alteração acaba ferindo princípios basilares da Seguridade Social, bem como direitos e garantias individuais assegurados na CF/88.

São considerados direitos e garantias individuais, os previstos constitucionalmente e ainda, protegidos por cláusula pétrea conforme art. $60, \S 4^{\circ}, \mathrm{IV}$ da $\mathrm{CF} / 88^{4}$. O direito à Previdência Social é um deles, constante no art. $6^{\circ}$ da Constituição ${ }^{5}$. Diante disso, não pode o poder constituinte derivado aprovar emendas que objetivem ferir direito fundamental como o direito à Previdência Social restringindo-o.

Com base na impossibilidade de abolição dos direitos assegurados pelas cláusulas pétreas, cita-se trecho da ACP 2004.61.83.005626-4 de (São Paulo, 2004, p. 17):

\begin{abstract}
A nossa Constituição ao estabelecer a possibilidade de sua reforma, também a limita, prescrevendo que não será objeto de deliberação a proposta de emenda tendente a abolir, entre outros, os direitos e garantias individuais. Assim, a Constituição não proíbe a alteração dos direitos individuais, mas a sua abolição.

Com a EC n ${ }^{\circ} 20 / 98$, não houve a alteração da proteção aos dependentes dos segurados que recebiam remuneração acima do limite que ela estabeleceu, mas a exclusão da proteção e, dessa forma, aboliu a proteção previdenciária aos mencionados dependentes, atingindo, assim, o núcleo essencial do direito fundamental à previdência, na situação de necessidade advinda do encarceramento do segurado.
\end{abstract}

\footnotetext{
${ }^{4}$ Art. 60. A Constituição poderá ser emendada mediante proposta:

[...] $\S 4^{\circ}$ - Não será objeto de deliberação a proposta de emenda tendente a abolir:

I - a forma federativa de Estado;

II - o voto direto, secreto, universal e periódico;

III - a separação dos Poderes;

IV - os direitos e garantias individuais.(grifo do autor)

5 Art. $6^{\circ}$ São direitos sociais a educação, a saúde, a alimentação, o trabalho, a moradia, o lazer, a segurança, a previdência social (grifo do autor), a proteção à maternidade e à infância, a assistência aos desamparados, na forma desta Constituição.
} 
Nota-se, portanto, que não ocorreu a alteração da remuneração que os dependentes recebiam a título de auxílio-reclusão, mas sim a exclusão da proteção de uma gama de pessoas que faziam jus ao seu recebimento.

O direito à Previdência Social é conhecido como fundamental quando é assegurado no art. $6^{\circ}$ da Constituição Federal como direito social. Como ensinam os doutrinadores, sua função é proteger os que, por motivos diversos, não possuam condições de exercer seus trabalhos para garantir o sustento próprio e de sua família. É nos momentos de dificuldade e contratempos, que a Previdência Social tem a função de manter o ser humano dentro de um nível existencial minimamente adequado.

Sobre o assunto, cita-se Daniel Machado da Rocha (2004, p. 113) que trata em seu livro específico sobre o assunto da seguinte forma: “[...] entendemos que o direito fundamental à previdência social goza de força jurídica privilegiada no inciso IV do artigo 60.”

A utilização do direito à previdência social como direito fundamental é baseada especificamente no direito de todos os contribuintes e seus dependentes usufruírem de benefícios em momentos de dificuldades e contingências. Diante deste propósito da previdência social, cita-se trecho do livro de Daniel Machado da Rocha (2004, p. 111) que fala sobre a influência direta que este direito possui:

\begin{abstract}
A doutrina nacional mais abalizada sobre direitos fundamentais também reconhece a íntima vinculação entre o direito à previdência social e a dignidade da pessoa humana, princípio basilar de todos os direitos sociais.
\end{abstract}

A relação existente entre o direito à Previdência Social e a dignidade da pessoa humana, faz com que a violação do primeiro desencadeie o desrespeito do segundo.

Sobre o direito fundamental da dignidade da pessoa humana cita-se Kildare Gonçalves Carvalho (2006, p. 465) que define o referido direito da seguinte forma:

No âmbito da Constituição brasileira de 1988, a dignidade da pessoa humana é o fundamento de todo o sistema dos direitos fundamentais, no sentido de que estes constituem exigências, concretizações e desdobramentos da dignidade da pessoa e que com base neste é que devem aqueles ser interpretados.

Depreende-se deste conceito, portanto, que o direito à dignidade da pessoa humana deve ser utilizado como base para a aplicação dos demais direitos. Ainda, quando a regra 
analisada desrespeitar as condições mínimas de existência do ser humano, estará em desacordo com o referido direito.

Diante da explanação do conceito, nota-se que a restrição da concessão do auxílioreclusão gera reflexos na dignidade da pessoa humana, conforme ensina o Juiz Federal Daniel Raupp (2009, p.2):

\begin{abstract}
Assim é reconhecida a existência, na Constituição, de direito fundamental à previdência social como decorrência do princípio da dignidade da pessoa humana (art. $1^{\circ}$, inc. III, da CR) porquanto confere a satisfação de necessidades existenciais básicas para uma vida com dignidade.
\end{abstract}

Depreende-se dos ensinamentos do autor supra que não se considera digno, deixar à deriva dependentes do segurado que possui renda superior ao permitido em lei, visto que tal renda pode ser a única da família, e uma vez cessada, deixará os dependentes em situação de penúria muitas vezes maior do que os dependentes do segurado efetivamente de baixa renda.

Considera-se ainda importante para a problemática da inclusão do requisito baixa renda, a impossibilidade prevista na Constituição, da pena passar da pessoa do acusado conforme art. $5^{\circ}, \mathrm{XLV}$ da $\mathrm{CF} / 88$ :

\footnotetext{
Art. $5^{\circ}$ Todos são iguais perante a lei, sem distinção de qualquer natureza, garantindose aos brasileiros e aos estrangeiros residentes no País a inviolabilidade do direito à vida, à liberdade, à igualdade, à segurança e à propriedade, nos termos seguintes:

[...] XLV - nenhuma pena passará da pessoa do condenado, podendo a obrigação de reparar o dano e a decretação do perdimento de bens ser, nos termos da lei, estendidas aos sucessores e contra eles executadas, até o limite do valor do patrimônio transferido;
}

Depreende-se desse ponto, portanto que, os dependentes não podem ser punidos pela falta cometida pelo segurado tendo em vista o caráter individual da pena. Cita-se os autores Vicente Paulo e Marcelo Alexandrino (2009, p. 157) que definem a aplicabilidade do princípio da pessoalidade da pena assim:

Em razão dessa regra, fica absolutamente afastada a possibilidade de a condenação penal estender-se a parentes, amigos ou sucessores do condenado, que não tenha participado da conduta por ele praticada. 
Tal entendimento possui também a autora Maruza Rubia Cavassana (2008, p. 38) que trata da restrição do auxílio-reclusão indicando que "Ao limitar o referido benefício, a emenda constitucional traz reflexos, penalizando também a família do preso."

Sobre o assunto cita-se ainda Eugênia Augusta Gonzaga Favero (2004, p. 206/207) que indica:

\begin{abstract}
ora, penalizar a família do condenado, ainda que ela tenha outras fontes de renda, é fazer com que a pena daquele que cometeu o crime ultrapasse sua pessoa, o que é vedado constitucionalmente (art. $5^{\circ}$, inc. XLV). Nem se alegue que o Estado não pode sustentar a família de quem está preso. Nesse caso, deve sim, porque se trata de benefício de quem era 'segurado' do INSS, ou seja, recolhia contribuições previdenciárias todo o mês e deve ter direito à cobertura integral para seus dependentes.
\end{abstract}

Ainda, segundo o Juiz Federal Hermes Gomes Filho (2010, p. 154), a aplicação do princípio é justificada pelo seguinte motivo:

Argumenta-se que os familiares do recluso já experimentaram o sofrimento pelo afastamento do seu convívio e ainda teriam que suportar a privação da fonte de renda, o que constituiria uma extensão da pena aos dependentes, os quais não concorreram para o crime que deu azo à prisão do segurado.

É notório, portanto que o posicionamento dos doutrinadores citados é no sentido de preocupar-se com a situação econômica em que restarão os dependentes do segurado recluso, uma vez que estes não podem ser penalizados por atos praticados pelo segurado.

A diferenciação dos segurados, que antes da Emenda Constitucional nº 20 de 1998 não existia, feriu também o princípio constitucional da universalidade da cobertura e do atendimento. Primeiramente é preciso citar os autores Carlos Alberto Pereira de Castro e João Batista Lazzari (2005, p.88) que definem o princípio como sendo:

Por universalidade da cobertura entende-se que a proteção social deve alcançar todos os eventos cuja reparação seja premente, a fim de manter a subsistência de quem dela necessite, A universalidade do atendimento significa, por seu turno, a entrega das ações, prestações e serviços de seguridade social a todos os que necessitem, tanto em termos de previdência social - obedecendo o princípio contributivo - como no caso da saúde e da assistência social.

No mesmo sentido segue o conceito sobre o princípio de Marina Vasques Duarte (2010, p.30), além de tratar deste como uma norma programática como segue:

Tal dispositivo configura-se como uma norma programática para o legislador, que deve, tanto quanto possível, tornar a seguridade social o mais universalizável possível. 
A idéia de que todos possam participar do sistema de previdência, assistência e saúde, dentro de sua necessidade. Assim, a proteção social deve alcançar todos os eventos cuja reparação seja premente a todos que necessitem (quanto à previdência social deve ser obedecido também o princípio contributivo).

Ao tratar o princípio da universalidade da cobertura e do atendimento como uma norma programática, o objetivo é que o Estado siga a tendência de ampliar a concessão do benefício aos segurados de forma gradativa. Sempre se deve observar que a aplicação deste princípio no ramo da Previdência Social pressupõe contribuição prévia, relembrando o princípio da preexistência do custeio e demais aplicados nas relações previdenciárias visto que um princípio nunca atua isoladamente.

Cita-se o exposto pelas Procuradoras da República na ACP (São Paulo, 2004, p. 22) sobre esse princípio conforme segue:

\begin{abstract}
A EC no 20/98 não limitou o valor a ser recebido, mas impediu o recebimento afetando, assim, o princípio da universalidade da cobertura e do atendimento (art. 194, parágrafo único, I, da $\mathrm{CF}$ ), o qual é dirigido à seguridade social. $\mathrm{O}$ mencionado princípio na área da Previdência Social, tem uma aplicação mais restrita: atinge todos os segurados e seus dependentes e não a toda população brasileira, como o que ocorre com a saúde.

Ora, a inovação da EC n ${ }^{\circ}$ 20/98 excluiu da proteção previdenciária parcela dos dependentes de segurados e, por essa razão, afeta o princípio da universalidade da cobertura e do atendimento, com as especificidades aplicáveis à subárea previdenciária.
\end{abstract}

Sobre este custeio necessário para a concessão do benefício, cita-se trecho do autor Fabio Zambitte Ibrahim (2011, p. 67):

[...]Além disso, toda a sociedade deve ser protegida, sem nenhuma parcela excluída. Obviamente este princípio é realizável, na medida em que recursos financeiros suficientes são obtidos. Não há como se criarem diversas prestações sem o custeio respectivo. A universalidade será atingida dentro da possibilidade do sistema.

Fica evidente que o princípio não é aplicado sozinho. Cabe aqui frisar que os segurados excluídos da gama que possui direito ao auxílio-reclusão, também são contribuintes da Previdência Social. Apenas distinguem-se dos que possuem direito ao recebimento do benefício, por contribuírem com valor superior ao permitido com a inovação da emenda.

Se a norma é programática, e sua tendência é sempre aumentar a proteção e garantir condições dignas aos que possuem a preexistência de custeio, então vetores como o requisito baixa renda não possuem espaço para aplicação. 
Nota-se, portanto que a entrada em, vigor da Emenda Constitucional $\mathrm{n}^{\circ} 20$ de 1998 contradiz o disposto neste princípio quando restringe o benefício ao invés de ampliá-lo. A falta de contribuição dos excluídos do recebimento, que seria fator aceitável, não existe, visto que o motivo da exclusão é a contribuição a maior que o permitido pela alteração da emenda por alguns segurados. É negado o benefício aos que são segurados e dependentes previdenciários e portanto, contribuem para a Previdência Social e não aos que não ostentam tais requisitos.

Com base em todos estes aspectos negativos decorrentes da aplicação da modificação feita pela Emenda Constitucional $n^{\circ} 20$, é evidente que o requisito baixa renda viola princípios e não deve permanecer no ordenamento jurídico.

A relação que existe entre o requisito baixa-renda e o princípio da igualdade é demonstrada com a violação dos direitos fundamentais e princípios que norteiam o ordenamento jurídico, fazendo com que os dependentes dos segurados que possuem renda superior ao limite fixado fiquem à deriva e sem a proteção jurídica.

Cita-se o juiz federal Daniel Raupp (2009, p. 4) o qual afirma que criação do requisito baixa-renda é inconstitucional e deve ser retirado do ordenamento jurídico:

Nesse contexto, a inovação trazida pela EC n. 20, ao excluir da proteção social os dependentes de segurado cuja renda bruta ultrapasse determinado valor deve ser tida como inconstitucional.

As Procuradoras da República destacam na ACP (São Paulo, 2004, p. 3) sobre a limitação da concessão do auxílio-reclusão o seguinte:

Considerando o fato de que o auxílio-reclusão foi criado com o objetivo de garantir a manutenção dos dependentes daquele que está encarcerado e que, portanto, encontrase impossibilitado de usufruir renda pelo exercício de atividade laboral, este limite monetário deve ser afastado, conforme será demonstrado a seguir. A aplicação do referido limite tem deixado os dependentes dos segurados, que antes da prisão recebiam além do citado limite, sem qualquer fonte de recursos para suas subsistências, já que não lhes é concedido o auxílio-reclusão.

Os autores Carlos Alberto Pereira de Castro e João Batista Lazzari (2005, p. 642) tratam sobre o tema da seguinte forma:

A redução do alcance do benefício, contemplado, após 16.12.1998, apenas as famílias dos segurados de "baixa renda", constitui discrímen não razoável, padecendo a regra de vício de inconstitucionalidade, por afetar o tratamento isonômico. Cumpre lembrar o precedente do salário-maternidade, que foi estabelecido na Constituição 
originariamente como sendo benefício previdenciário a ser concedido "sem prejuízo do emprego e do salário", razão pela qual o STF considerou a alteração promovida pela EC 20/98 (limitação ao teto RGPS) inconstitucional. Aqui, a situação é idêntica, pois o escopo da proteção social é a proteção universal a quaisquer pessoas que se encontrem em condição de risco de subsistência, e não é razoável se admitir que renda familiar no valor de $\mathrm{R} \$$ de 360,00 (à época da EC 20/98) indique ter a família condições de manter-se sem o benefício do auxílio-reclusão, ainda mais quando não se leva em conta o número de pessoas a ser mantida.

Nota-se que todos os autores que concordam com a tese de impossibilidade de aplicação do requisito baixa-renda no auxílio-reclusão, apontam a proximidade do auxílioreclusão com o salário-família, observando que este é benefício complementar de renda, enquanto aquele é benefício substitutivo.

São muitos os motivos que levam a inviabilidade de aplicação do requisito implantado pela Emenda Constitucional n ${ }^{\circ} 20$ de 1998, como demonstra Wladimir Novaes Martinez (2009, p. 117):

Altera-se significativamente o auxílio-reclusão, passando a ser direito do mesmo trabalhador que faz jus ao salário família: segurado de baixa renda. A modificação do benefício, para pior, é incompreensível e discriminatória, convindo suscitar a impropriedade em face de outros postulados fundamentais da Lei maior.

Cita-se ainda o Juiz Federal Daniel Raupp (2009, p.7) que indica que "nesse contexto, a inovação trazida pela Emenda Constitucional n ${ }^{\circ} 20$ de 1998, ao excluir da proteção social os dependentes de segurado cuja renda ultrapasse determinado valor, deve ser tida como inconstitucional."

O fato de considerar o requisito baixa-renda inconstitucional é baseado em vários fatores, porém um dos mais importantes é o fato de que os dependentes do segurado com renda superior também carecem do recebimento do auxílio-reclusão que é benefício de caráter substitutivo de renda.

Conforme já salientado anteriormente, o benefício substitui a renda do segurado que é recolhido à prisão e, portanto, não possui forma de prover o sustento de sua família. A falta de sustento da família é o centro de uma "teia" de motivos que tornam discutível a restrição do benefício ao requisito baixa-renda.

Nota-se que os dependentes do segurado de renda superior ficam desamparados, conforme o Juiz Federal Daniel Raupp (2009, p.7) trata: 
justamente substituir os rendimentos do segurado preso, portanto impedindo de trabalhar. Seja a hipótese de família carente, seja de família abastada, o fundamento è o mesmo: da ausência do individuo provedor decorre a necessidade de substituição por prestação previdenciária, presumindo-se a necessidade dos dependentes.

Assim, ainda que o objetivo da restrição fosse a redução das desigualdades sociais, o critério escolhido para tanto, não justifica a exceção do princípio da igualdade.

Sobre essa diferenciação é preciso lembrar o disposto no item do princípio da igualdade, onde um dos critérios necessários para a desigualação dos desiguais é citado por Celso Antônio Bandeira Mello (1990, p. 51) que é justamente o seguinte: “b) Que as situações ou pessoas desequiparadas pela regra de direito sejam efetivamente distintas entre si, vale dizer, que possuam características, traços, nelas residentes, diferençados." É válida portanto a distinção desde que os critérios adotados sejam plausíveis.

Sobre a validade do requisito baixa-renda para aplicar tratamento desigual cita-se Celso Ribeiro Bastos (2002, p. 319) que trata dos critérios que podem ser considerados válidos para desigualar e diz:

[...]o caráter inconstitucional da discriminação não repousa tão-somente no critério escolhido, mas na falta de correlação lógica entre aquele critério e uma finalidade ou valor encampado quer expressa ou implicitamente no ordenamento jurídico, quer ainda na consciência coletiva.

É notório que diante de todos os reflexos negativos aos segurados e aos dependentes, a Emenda gerou limitação da concessão do auxílio-reclusão e ocorreu o desrespeito ao princípio da isonomia, acabando por gerar situações desconfortáveis aos dependentes descobertos pela concessão do benefício auxílio-reclusão.

Assim, resultado da análise de todos os pontos anteriormente explanados conclui-se de que o requisito baixa-renda desrespeita o princípio da igualdade, surgindo o conceito de igualdade previdenciária. Diferente daquela conceituada em livros, essa igualdade é relacionada à solidariedade social, embora não tenha o mesmo conceito. A solidariedade social aplicada na saúde e na assistência social busca a contribuição de muitos para beneficiar alguns, sendo um sistema válido já que beneficia em grande parte pessoas com renda inferior. Essa mesma solidariedade aplicada na Previdência Social deveria fazer com que todos contribuíssem com valores variáveis de acordo com sua renda mensal para que, futuramente, todos pudessem usufruir dos benefícios oferecidos caso precisassem. 
Porém com o advento do requisito baixa-renda, ocorre a restrição do benefício no momento da concessão, embora o segurado tenha vertido contribuições para ter direito ao benefício.

A igualdade previdenciária nada mais é do que a aplicação da solidariedade social às avessas. Isso ocorre porque o conceito de solidariedade utilizado neste caso acaba sendo o aplicado no âmbito da saúde e da assistência com a contribuição de muitos em prol de alguns. Não é correto, porém tal aplicação já que o benefício auxílio-reclusão integra a Previdência Social e, portanto, a solidariedade aplicada deveria ser a da contribuição em valores diferenciados e o recebimento do benefício de todos os contribuintes caso precisassem, fundamentalmente os que são substitutivos de renda. Com a aplicação da solidariedade de forma incorreta, surge uma forma de igualdade diferente, que foi neste trabalho denominada de previdenciária.

\section{CONSIDERAÇÕES FINAIS}

Diante das longas pesquisas e explanações sobre os assuntos expostos, é possível então concluir que a concessão do auxílio-reclusão não tem a aplicação do princípio da igualdade da forma correta. Isto acarreta o desrespeito a uma série de princípios constantes no ordenamento jurídico e deixa à deriva famílias inteiras que dependem da renda do segurado recluso para sobreviver.

É inaceitável que ainda hoje esta regra incoerente seja aplicada e a população em geral pareça não se importar com isso. Que o benefício auxílio-reclusão é tratado com pouca importância pela sociedade não é novidade, porém, não é aceitável que uma regra prejudique famílias inteiras pelo descaso ou falta de informação do povo, acrescido de uma má aplicação jurídica realizada pelo legislativo.

É preciso que o preconceito que rodeia este benefício seja deixado de lado e as famílias dos presos sejam tratadas com a dignidade e o respeito que merecem, visto que são tão merecedoras de benefício previdenciário quanto os dependentes que adquirem direito à pensão por morte. A pena não pode ser imposta à família do apenado, porém, o total desamparo econômico é por vezes mais severo que qualquer pena restritiva de liberdade. 
Não se pode privar dependentes, que não raras vezes são crianças, de um benefício que necessitam por critérios absurdos e incompatíveis com a ideia de igualdade tão almejada pelo poder constituinte originário com a Lei Maior.

Para que esse requisito baixa-renda mude, é preciso primeiro que as pessoas desmistifiquem este benefício e que ele deixe de ser conhecido como "auxílio bandido" e passe a ser aceito pelo real objetivo que possuí. Só assim o requisito baixa-renda será visto por todos como a aberração jurídica que é e será então retirado da Constituição.

\section{REFERÊNCIAS}

Ação Civil Pública $n^{\circ}$ 2004.61.83.005626-4. Procuradoria da República de São Paulo. Petição inicial firmada pelas Procuradoras Eugênia A. Gonzaga Fávero e Zélia Luiza Pierdoná. p. 01 32.

BARBOSA, Rui. Oração aos Moços. Edição popular anotada por Adriano da Gama Kury. $5^{\text {a ed. }}$ Rio de Janeiro: Fundação Casa de Rui Barbosa, 1999.

BRASIL,Constituição da República Federativa do Brasil de 1988. Disponível em www.planalto.gov.br. Acesso em: 07 de set. de 2016.

BRASIL. Decreto 3048, de 06 de maio de 1999. Aprova o regulamento da Previdência Social e dá outras providências. Diário Oficial da República Federativa do Brasil, Brasília, DF, 7 maio 1999. Disponível em: 〈http://www.planalto.gov.br/ccivil_03/decreto/d3048.htm>. Acesso em: 11 set. 2016.

BASTOS, Celso Ribeiro. Curso de Direito Constitucional. São Paulo: Celso Bastos, 2002.

CARVALHO, Kilarde Gonçalves. Direito Constitucional - Teoria do Estado e da Constituição Direito Constitucional Positivo. 12a ed. Ver. e atual. Belo Horizonte: Del Rey, 2006.

CASTRO, Carlos Alberto Pereira de; LAZZARI, João Batista. Manual de Direito Previdenciário. $6^{\mathrm{a}}$ ed. São Paulo: LTr, 2005.

CAVASSANA, Maruza Rubia. O auxílio-reclusão. Revista de Direito Social, Porto Alegre, Ano VIII, n. 32, p. 13-44, out./dez. 2008.

DUARTE, Marina Vasques. Direito previdenciário. $7^{\mathrm{a}}$ ed. Porto Alegre: Verbo Jurídico, 2010.

FAVERO, Eugênia Augusta Gonzaga. Direitos das Pessoas com Deficiências: garantia de igualdade na diversidade. Rio de Janeiro: WVA, 2004. 
FILHO, Manuel Gonçalves Ferreira. Curso de Direito Constitucional. $34^{\mathrm{a}} \mathrm{ed}$, rev.e atual. São Paulo: Saraiva, 2008.

GOMES FILHO, Hermes. O benefício de auxílio-reclusão - legislação e interpretação jurisprudencial atualizadas. Anais da I Jornada de Direito Previdenciário, Escola da Magistratura Federal da 1ª Região, Brasília, 2010.

IBRAHIM, Fábio Zambitte. Curso de Direito Previdenciário. 16a ed. Rio de Janeiro: Impetus, 2011.

MARTINEZ, Wladimir Novaes. Reforma da Previdência Social: Comentários à Emenda Constitucional no 20/98. São Paulo: LTr, 2009.

MELLO, Celso Antônio. Regime Constitucional dos servidores da administração direta e indireta. São Paulo: RT, 1990.

PAULO, Vicente; ALEXANDRINO, Marcelo. Direito Constitucional Descomplicado. $4^{\mathrm{a}}$ ed. rev. atualizada. São Paulo: Método, 2009.

Portaria Interministerial MPS/MF n 01 de 08/01/2016. Disponível em www.previdência.gov. br. Acesso em: 07 de set. de 2016.

RAUPP, Daniel. Auxílio-reclusão: inconstitucionalidade do requisito baixa renda. Disponível em: http://www2.cjf.jus.br/ojs2/index.php/cej/article/viewFile/1090/1278. Acesso em: $07 \mathrm{de}$ set. de 2016.

ROCHA, Daniel Machado da. O Direito Fundamental à Previdência Social na Perspectiva dos Princípios Constitucionais Diretivos do Sistema Previdenciário Brasileiro. Porto Alegre: Livraria do Advogado, 2004.

ROCHA, Daniel Machado da; BALTAZAR JUNIOR, José Paulo. Comentários à Lei de Benefícios da Previdência Social. $3^{\mathrm{a}}$ ed. Porto Alegre: Livraria do Advogado, Esmafe, 2003. 